\title{
GURU ADALAH MANAJER SESUNGGUHNYA DI SEKOLAH
}

\author{
Heriyansyah \\ STAI Al Hidayah Bogor \\ heristaia@gmail.com
}

\section{ABSTRACT}

This research entangle two variable, namely free variable that is leadership influence studied by through dimension covering leadership function (X1); leadership style (X2); leadership duty (X3), leadership role (X4) and variable trussed by that is interest teach the teacher $(Y)$. Research conducted by on the basis of method correlational to measure the certain variable influences to variable of is other. Analysis of result of research apply the level of regresi and correlation of multilepel and also parsial. This matter as according to hypothesis raised and also conditions of about measurement scale which is at least interval can be fulfilled. Beside that, data of result of research tested by the condition normalitas, because data taken by a correctness come from population which have normal distribution. From research result show the existence of influence usher the variable. This matter is seen from; (1) Leadership function to interest teach the teacher obtained by correlation coefficient of equal to ry $1=0,2441$ or $r$ ? 0,20. This number indicate that the leadership function have an effect on to interest teach the teacher, (2) Leadership Style to teacher interest obtained by correlation ry2 $=0,2008$ or $r$ ? 0,20. This number indicate that the leadership style have an effect on to interest teach the elementary schoolteacher, (3) Leadership duty to interest teach the teacher obtained by correlation coefficient ry3 $=0,2106$ or $r$ ? 0,20. This matter show that leadership duty have an effect on to interest teach the teacher, (4) Leadership role to interest teach the teacher, from result analyse by using simple linear test, is namely obtained by value of regresi $Y=11,74$ $+0,95 x$. While on the basis of test $F$ obtained by Fcount 66,56 and Ftable $=$ 0,00001 . Result analyse the showing that leadership role to interest teach the teacher. Result of the analysis indicate that the leadership to interest teach the teacher $36 \%$ influenced by leadership role which kondusif.Result of analysis of concerning leadership role which condushif, on the basis of frequency distribution qualitative indicate that $64 \%$ from all teacher not yet full of playing a part in to run its leadership in executing of duty and responsibility becoming its obligation. Basically when leadership consisted of by the function, style, and duty executed directionally and inwrought, undoubtedly can grow the leadership role of all Elementary schoolteacher of country. This Matter is known from result analyse the correlation coefficient which showingr $=0,6371$ and coefficient of determination $r 2=0,4059$, burden that leadership role of all teacher to interest teach the teacher $40,59 \%$ influence by function, style and leadership duty.

Keywords: teacher, leadership and manager 


\section{ABSTRAK}

Penelitian ini melibatkan dua variabel, yaitu variabel bebas berupa pengaruh kepemimpinan yang dipelajari melalui dimensi yang meliputi fungsi kepemimpinan (X1); gaya kepemimpinan (X2); tugas kepemimpinan (X3), dan peran kepemimpinan (X4) dan variabel terikat dengan itu adalah minat mengajar guru $(Y)$. Penelitian yang dilakukan berdasarkan metode korelasional untuk mengukur variabel tertentu berpengaruh terhadap variabel lain. Analisis hasil penelitian menerapkan tingkat regresi dan korelasi multilepel dan juga parsial. Hal ini sesuai dengan hipotesis yang diangkat dan juga kondisi tentang skala pengukuran yang paling sedikit intervalnya bisa terpenuhi. Disamping itu, data hasil penelitian diuji dengan kondisi normalitas, karena data yang diambil dengan benar berasal dari populasi yang memiliki distribusi normal. Dari hasil penelitian menunjukkan adanya pengaruh antar variabel. Matte ini terlihat dari; (1) Fungsi kepemimpinan terhadap minat mengajar guru diperoleh dengan koefisien korelasi sebesar ry $1=0,2441$ atau $r$ ? 0,20. Angka ini menunjukkan bahwa fungsi kepemimpinan berpengaruh terhadap minat mengajar guru, (2) Gaya Kepemimpinan terhadap minat guru diperoleh korelasi ry2 $=0,2008$ atau $r$ ? 0,20. Angka ini menunjukkan bahwa gaya kepemimpinan berpengaruh terhadap minat mengajar guru sekolah dasar, (3) Tugas Kepemimpinan untuk kepentingan mengajar guru diperoleh dengan koefisien korelasi ry3 $=0,2106$ atau $r ? 0,20$. Hal ini menunjukkan bahwa tugas kepemimpinan berpengaruh terhadap minat mengajar guru, (4) Peran kepemimpinan terhadap minat mengajar guru, dari hasil analisis dengan menggunakan uji linier sederhana, yaitu diperoleh nilai regresi $Y=11,74+0$, 95x. Sedangkan berdasarkan uji $F$ diperoleh $\mathrm{F}$ hitung 66,56 dan $\mathrm{F}$ tabel $=0,00001$. Hasil analisis menunjukkan bahwa peran kepemimpinan terhadap minat mengajar guru. Hasil analisis menunjukkan bahwa kepemimpinan terhadap minat mengajar guru 36\% dipengaruhi oleh peran kepemimpinan yang kondusif. Hasil analisis mengenai peran kepemimpinan yang condushif, berdasarkan distribusi frekuensi kualitatif menunjukkan bahwa 64\% dari seluruh guru belum penuh berperan dalam menjalankan kepemimpinannya dalam menjalankan tugas dan tanggung jawab menjadi kewajibannya. Pada dasarnya ketika kepemimpinan terdiri dari fungsi, gaya, dan tugas yang dijalankan secara terarah dan tempur, tidak diragukan lagi dapat menumbuhkan peran kepemimpinan semua guru sekolah dasar di negara tersebut. Hal ini diketahui dari hasil analisis koefisien korelasi yang menunjukkan $r=0,6371$ dan koefisien determinasi $r 2=$ 0,4059 , beban bahwa peran kepemimpinan semua guru terhadap minat mengajar guru 40,59\% dipengaruhi oleh fungsi, gaya, dan tugas kepemimpinan.

Kata Kunci : guru, pemimpin, manajer.

\section{PENDAHULUAN}

Salah satu tantangan yang dihadapi bangsa Indonesia pada zaman modern ini adalah masalah rendahnya mutu sumber daya manusia, kemudian upaya untuk meningkatkan sumber daya manusia tersebut di antaranya adalah melalui pendidikan. Jadi pendidikan merupakan salah satu keilmuan dan lain sebagainya.

Makna pendidikan secara sederhana dapat diartikan sebagai usaha manusia untuk membina kepribadiannya sesuai dengan nilai-nilai di dalam 
masyarakat dan kebudayaan. Pendidikan pada hakekatnya merupakan usaha manusia melestarikan hidupnya.

Pendidikan sebagai sarana sosialisasi merupakan kegiatan manusia yang melekat dalam kehidupan masyarakat, sehingga usia pendidikan hampir sama dengan usia manusia dalam berbagai rentang peradaban. (Wardiman Djojonegoro: 1996: 1).

Kualitas pendidikan yang dicanangkan dalam Mukadimah Atas Perbukaan Undang-undang dasar 1945, adalah memajukan kesejahteraan umum dan mencerdaskan kehidupan bangsa. Untuk itu usaha nyata yang amat penting adalah memantapkan berbagai program pemerintah dalam program pembangunan kualitas pendidikan di Indonesia.

Pendidikan Nasional diselenggarakan secara terprogram, berjenjang, berkelanjutan, dan sangat fundamental bagi upaya mencerdaskan kehidupan bangsa, taraf hidup, kesejahteraan, kualitas sumber daya manusia, dan martabat bangsa Indonesia.

Maksud dan tujuan dari pendidikan Nasional adalah meningkatkan kualitas manusia Indonesia yang beriman, bertakwa, berbudi pekerti luhur, berkepribadian, mandiri, disiplin, profesional, bertanggung jawab, dan produktif. Hal tersebut menuntut dukungan kemampuan kerja dari segenap pelaksana pendidikan untuk menyelenggarakan pendidikan yang efektif, sehingga mampu menciptakan proses belajar mengajar yang dapat menumbuhkan rasa percaya diri, serta berkembangnya budaya belajar agar tumbuh sikap dan prilaku yang kritis, kreatif, inofatif, dan produktif serta mendorong keinginan untuk maju. Menciptakan manusia-manusia seperti yang diharapkan tidak lepas dari peranan tenaga guru sebagai tenaga pengajar dalam konteks pendidikan formal.

Pembangunan dalam bidang pendidikan pada dasarnya merupakan wujud nyata dari perjuangan untuk meningkatkan kesejahteraan umum dan mencerdaskan kehidupan bangsa yang menjadi bagian dari cita-cita Nasional seperti yang diamanatkan dalam Pembukaan Undang-Undang Dasar 1945.

Dalam hal ini, sekolah sebagai lembaga penyelenggara pendidikan formal sangatlah penting dan berperan dalam memajukan sumber daya manusia karena di dalamnya terdapat kegiatan proses belajar mengajar yang 
teratur dan terencana. Agar kegiatan proses belajar mengajar berjalan dengan baik, maka harus ada seorang pemimpin yang dapat mengatur dan mengelola kegiatan proses belajar mengajar di sekolah. Seorang pemimpin dalam proses belajar mengajar dapat disebut sebagai "guru". Secara sederhana, Wahjosumidjo mendefinisikan guru sebagai pemimpin (manager) adalah: "seorang tenaga fungsional yang diberi tugas untuk memimpin proses pembelajaran bagi peserta didik yang diselenggarakannya, atau tempat terjadinya interaksi antara guru yang memberi pelajaran dan murid yang menerima pelajaran". (Wahjosumidjo;1999:83)

Dalam lembaga pendidikan guru sebagai pemimpin (manager) yang memberikan materi pelajaran dan sekaligus sebagai pendidik agar anak pintar dan juga berakhlak mulia (terpuji). Jadi jelas seorang pemimpin mempunyai tugas sebagai manajer yang menggerakkan semua orang yang terkait agar dapat melaksanakan tugasnya dengan baik. Di sisi lain, guru masa depan tidak tampil lagi sebagai pengajar (teacher) seperti fungsinya yang menonjol selama ini, melainkan beralih sebagai pelatih (coach), pembimbing (counselor), dan manajer belajar (learning manager) (Rahendra Maya, 2013: 284).

Salah satu kunci keberhasilan suatu sekolah terletak pada kepemimpinan kepala sekolah itu sendiri. Tercapainya program pendidikan dan tercapainya tujuan pendidikan sangat tergantung kepada peran guru sebagai pemimpin pembelajaran di kelas. Karena itulah peranan guru sangatlah penting untuk kemajuan sekolah itu sendiri. Guru harus berperan aktif dalam menjalankan tugasnya, terutama dalam kegiatan proses belajar mengajar didalam kelas. Selain peran dari guru, maka anak didik pun berperan dalam proses belajar mengajar tersebut. Karena itu, menurut Syaiful Djamarah bahwa: "Guru dan anak didik merupakan dua sosok manusia yang tidak dipisahkan dari dunia pendidikan. Boleh jadi dimana ada anak didik disana ada guru yang ingin memberikan binaan dan bimbingan kepada anak didik".(Syaiful Djamarah: 2000:2). Sementara itu, menurut Nana Sujana, belajar dan mengajar merupakan dua konsep yang tidak bisa dipisahkan satu sama lain. Belajar menunjuk pada apa yang harus dilakukan orang sebagai subjek yang menerima pelajaran (sasaran didik), sedangkan 
mengajar menunjuk pada apa yang harus dilakukan oleh guru sebagai pendidik." (Nana Sudjana :1995:43).

Di dalam kegiatan belajar mengajar, kualitas pembelajaran terletak kepada guru karena memegang peranan yang sangat penting walaupun unsur-unsur lain ada seperti; kurikulum, tata usaha dan sarana prasarana juga dapat mendukung kualitas pembelajaran tersebut. Namun walaupun guru sangat mendukung di dalam pendidikan dan pengajaran, akan tetapi peran aktif sebagai pemimpin di kelas sangat dibutuhkan. Sebab guru merupakan "motor penggerak" bagi para siswa. Untuk itu guru harus mampu mengatur dan menstimulir para siswanya dalam mengembangkan metode mengajar dan memberikan motivasi dalam hal pelaksanaan tugas belajar dan tugas-tugas lain di sekolah, dengan demikian peranan guru sebagai manajer amatlah penting dalam pelaksanaan pendidikan di sekolah.

\section{TINJAUAN TEORITIS}

Dalam pengertian yang sederhana, guru adalah orang yang memberikan ilmu pengetahuan kepada anak didik. Guru dalam pandangan masyarakat adalah yang melaksanakan pendidikan di tempat-tempat tertentu, tidak mesti di lembaga pendidikan formal, tetapi bisa juga di masjid, di surau, di mushola, di rumah, dan lain sebagainya.

Menurut N.A. Ametambun dan Djamarah (1994:33), guru adalah semua orang yang bertanggung jawab terhadap pendidikan murid-murid, baik secara individual ataupun klasikal, baik di sekolah maupun di luar sekolah.

Dengan demikian seorang guru harus menguasai berbagai kompetensi baik pedagogis, kepribadian, sosial kemasyarakatan maupun Profesional. Sebagaimana dikemukakan oleh Wursanto, bahwa guru dalam sebuah lembaga pendidikan merupakan jabatan fungsional. Jabatan fungsional adalah jabatan yang ditinjau dari segi fungsi yang tidak tampak dalam struktur organisasi. (IG Wursanto;1992 : 40).

Guru merupakan jabatan atau profesi yang memerlukan suatu keahlian khusus, pekerjaannya tidak dapat dilakukan oleh sembarang orang tanpa memiliki keahlian sebagai guru. Orang yang pandai berbicara sekalipun belum dapat disebut sebagai guru. Untuk menjadi seorang guru 
diperlukan syarat-syarat khusus, apalagi sebagai guru yang profesional yang harus menguasai benar seluk-beluk pendidikan dan pengajaran dengan berbagai ilmu pegetahuan lainnya yang perlu dibina dan dikembangkan melalui masa pendidikan tertentu. (Uzer Usman: 1997:1-2).

\section{Kompetensi Guru}

Kompetensi guru dalam Undang-undang No 14 Tahun 2005 tentang Guru dan Dosen disebutkan bahwa; Kompetensi adalah seperangkat pengetahuan, keterampilan, dan perilaku yang harus dimiliki, dihayati, dan dikuasai oleh guru atau dosen dalam melaksanakan tugasnya. (UU RI NO 14: $2005: 4)$

Selanjutnya dalam Pasal 10 Undang-Undang No 14 Tahun 2005 tentang Guru dan Dosen dijelaskan kompetensi guru meliputi: kompetensi pedagogik, kompetensi sosial, kompetensi kepribadian, dan kompetensi profesional yang diperoleh melalui pendidikan profesi (UU RI NO 14:2005:9).

\section{Kompetensi Pedagogik}

Kompetensi pedagogik merupakan kemampuan guru dalam (i) mendidik para siswa dalam rangka pencapaian tujuan pendidikan pada setiap jenjang pendidikan, (ii) merencanakan dan melaksanakan program pembelajaran dan melakukan evaluasi pembelajaran berpegang pada prinsip perkembangan psikologis anak/peserta didik, dan (iii) mengembangkan keterampilan hidup anak/peserta didik.

\section{Kompetensi Kepribadian}

Kepribadian adalah keseluruhan dari individu yang terdiri dari unsur psikis dan fisik. (Syaiful Bahri Djamarah: 1994:58). Dengan demikian dalam kepribadian tercermin dalam seluruh sikap, perbuatan maupun tingkah laku yang terdapat dalam diri seseorang.

Menurut Uzer Usman kompetensi pribadi guru meliputi; a) Pengembangan kepribadian yang beriman dan bertakwa kepada Tuhan Yang Maha Esa, berperan aktif dalam masyarakat dan mengembangkan sifat-sifat terpuji, b) Berinteraksi dan berkomunikasi dengan teman sejawat guna meningkatkan kemampuan dan wawasannya dan dengan masyarakat 
guna menjalankan misi pendidikan, c) Melaksanakan bimbingan dan penyuluhan bagi siswa yang mengalami kesulitan belajar, kelainan, dan berbakat khusus, dan d) Melaksanakan administrasi sekolah, melaksanakan penelitian sederhana untuk keperluan pembelajaran.

Sedangkan menurut Mulyasa kepribadian yang harus dimiliki guru meliputi; a) Beriman dan bertakwa, b) Berwawasan Pancasila, c) Mandiri penuh tanggung jawab, d) Berwibawa, e) Berdisiplin, f) Berdedikasi, g) Bersosialisasi dengan masyarakat, dan h) Mencintai peserta didik dan peduli terhadap pendidikan (E.Mulyasa: 2002: 190-191).

Berdasarkan hasil penelitian yang dilakukan oleh Frend W. Hart terhadap 3.725 peserta didik Sekolah Menengah Atas di Amerika Serikat disimpulkan sepuluh sikap yang disenangi peserta didik terhadap kepemimpinan gurunya antara lain; a) Suka menolong pekerjaan sekolah dan menerangkan pelajaran dengan jelas dan mendalam serta menggunakan contoh-contoh yang baik dalam mengajar, b) Periang dan gembira, memiliki perasaan humor, dan suka menerima lelucon atas dirinya, c) Bersikap bersahabat, merasa sebagai anggota dalam kelompok kelas, d) Menaruh perhatian dan memahami muridnya, e) Berusaha agar pekerjaan menarik, dapat membangkitkan keinginan-keinginan bekerjasama dengan murid-murid, f) Tegas, sanggup menguasai kelas dan dapat membangkitkan rasa hormat pada anak didik, g) Tidak ada yang lebih disenangi, dan tak pilih kasih, taka da anak emas atau anak tiri, h) Tidak suka ngomel, mencela dan sarkatis, i) Anak didik benar-benar merasakan, bahwa ia mendapatkan sesuatu dari guru, dan j) Mempunyai pribadi yang dapat diambil contoh dari pihak anak didik dan masyarakat lingkungannya. (Syaiful Bahri Djamarah : 1994:63).

\section{Kompetensi Sosial (Kemasyarakatan)}

Tugas kemanusiaan masyarakat salah satu segi dari tugas guru, sisi ini tidak bisa guru abaikan, karena guru harus terlibat dalam kehidupan di masyarakat dengan interaksi sosial. Guru harus menanamkan nilai-nilai kemanusiaan kepada anak didiknya. Dengan begitu anak didik akan mempunyai sifat kesetiakawanan sosial.

Guru harus menempatkan diri sebagai orangtua kedua, dengan mengemban tugas yang dipercayakan orangtua wali murid dalam jangka 
waktu tertentu, untuk itu pemahaman terhadap jiwa dan watak anak didik diperlukan agar dapat dengan mudah memahami jiwa dan watak anak didik. Begitulah tugas guru sebagai orangtua kedua, setelah orangtua anak didik di dalam keluarga di rumah.

Di bidang kemasyarakatan merupakan tugas guru yang tidak kalah pentingnya, pada bidang ini guru mempunyai tugas mendidik dan mengajar masyarakat untuk menjadi warga negara Indonesia yang bermoral, memang tidak dapat dipungkiri bila guru mendidik anak didik sama halnya guru mencerdaskan bangsa Indonesia.

\section{Kompetensi Profesional}

Menurut E. Mulyasa, seorang guru perlu memiliki kompetensi mengajar yang dikenal dengan istilah kompetensi profesional. (E. Mulyasa: 2002:8). Secara khusus yang dimaksud dengan kompetensi professional adalah kompetensi dasar tentang disiplin ilmu yang dipelajarinya atau yang menjadi bidang spesialisasinya baik penguasaan teoritis maupun praktis, kemampuan didaktis, metodik, psikologis, keterampilan perencanaan serta kemampuan mengevaluasi hasil belajar mengajar.

Sementara itu, menurut M.Hidayat Ginanjar (2015:1019), guru harus benar-benar menguasai materi pelajaran dan ilmu mendidik. Hal ini bisa dilakukan dengan studi lanjut sesuai dengan spesialisasi, pelatihan, work shop, maupun studi banding ke institusi-institusi yang sudah maju. Demikian juga perlunya pembinaan dan pelatihan tentang peningkatan motivasi belajar terhadap siswa. Harus ditanamkan pola pembelajaran yang berorientasi proses bukan hasil, sehingga siswa akan terbiasa untuk belajar maksimal dengan mementingkan pada substansi bukan formalitas. Profesi guru harus dihargai dengan maksimal.

Oleh karena itu seorang guru harus mampu mengembangkan tiga aspek kompetensi, yaitu: 1) kompetensi pribadi, 2) kompetensi profesi, dan 3) kompetensi sosial/kemasyarakatan. (Hadari Nawawi;1985:123-124). Begitu juga mengenai kompetensi pribadi, yakni pentingnya memiliki sikap kepribadian yang mantap atau matang sehingga mampu berfungsi sebagai sumber identifikasi bagi siswa, dan dapat menjadi panutan dan penuntun bagi siswa dan masyarakatnya. Kompetensi profesi berkaitan erat dengan 
kemampuan edukatif dan administratif guru dalam bidang atau keilmuannya, yakni bahwa setiap guru perlu memiliki pengetahuan yang luas dan dalam mengenai materi yang harus diajarkan serta menguasai metodologi pengajaran yang meliputi konsep teoritis dan praktis.Sedangkan kompetensi kemasyarakatan dianggap sebagai kompetensi umum yang wajib dimiliki oleh setiap guru yaitu mampu beradaptasi dengan lingkungan baik di dalam maupun di luar lembaga pendidikan.

Dari pendapat dan teori yang dikemukakan para ahli, kompetensi guru adalah perpaduan dari pengetahuan, keterampilan, nilai dan sikap yang direfleksikan dalam kebiasaan berfikir dan bertindak berupa motivasi, ciri pembawaan (trait), konsep diri, sikap atau nilai, pengetahuan (content knowledge), atau keterampilan kognitif atau keterampilan perilaku dalam mendidik dan membimbing peserta didik yang meliputi paedagogis, kepribadian, sosial kemasyarakatan, dan profesi.

Adapun dimensi kompetensi guru meliputi penguasaan bahan pelajaran, merencanakan program mengajar, mengelola kelas, melaksanakan proses belajar mengajar, evaluasi prestasi belajar siswa, melaksanakan program bimbingan, penelitian kependidikan, sikap, dan penampilan.

Jadi dapat di sintesiskan bahwa beberapa kompetensi mengajar itu antara lain; 1) Seperangkat pengetahuan keterampilan, 2) Nilai dan sikap yang direfleksikan dalam kebiasaan berfikir dan bertindak, 3) Motivasi, ciri pembawaan (trait), dan 4) Konsep diri, sikap atau nilai, pengetahuan (content knowledge), atau keterampilan kognitif atau keterampilan prilaku dalam mendidik dan membimbing peserta didik.

\section{Keterampilan Guru Mengelola Kelas (Classroom management)}

Seorang guru harus menguasai sejumlah keterampilan dasar yang harus dimiliki agar dalam mengerjakan tugas profesionalnya berhasil secara optimal. Menurut para ahli pendidikan dari Stanford University dan Sydney University seperti dikutip Wina Sanjaya (2002:156) teridentifikasi 23 jenis keterampilan mengajar, sebagai berikut; 1) Establishing set, 2) Establishing appropriate frame of reference, 3) Achieving closure, 4) Recognizing and obtaining attending behavior, 5) Providing feedback, 6) Employing rewards 
and punishment (reinforcement), 7) Control of participation, 8) Redudancy and repetition, 9) Illustrating and use of example, 10) Asking questions (basic), 11) The use of difergent questions, 12) The use of higher order questions, 13) The use of probing questions, 14) Student-initiated questions, 15) Completeness of communication, 16) Varying the stimulus situation, 17) Lecturing, 18) Precuing, 19) Classroom managements and discipline, 20) Guiding small group discussion, 21) Small group teaching and individualized instruction, 22) Guiding discovery learning and fostering creativity.

Seperti telah disebutkan di atas salah satu keterampilan dasar yang harus dimiliki guru dalam mengajar adalah "Classroom management" atau keterampilan mengelola kelas. Keterampilan mengelola kelas penting untuk dikuasai oleh siapapun yang menerjunkan dirinya ke dalam dunia pendidikan terutama guru.

Pengelolaan kelas sangat penting dalam kegiatan pembelajaran, karena dalam melakukan kegiatan belajar siswa memiliki berbagai kebutuhan seperti teori kebutuhan yang dikemukakan oleh Maslow. Maslow menyebutkan pada setiap manusia ada lima hirarki kebutuhan yaitu: fisiologis, rasa aman, rasa memiliki dan dicintai, penghargaan serta aktualisasi. (Sumber: Judith R. Gordon. 1991. A diagnostic to Organizational Behavior)

Dari berbagai tingkatan kebutuhan manusia yang dikemukakan oleh Maslow di atas adalah kebutuhan rasa aman. Dalam kegiatan belajar di kelas, rasa aman dalam belajar akan dirasakan oleh siswa apabila guru dapat melakukan pengelolaan kelas dengan baik.

Mengelola kelas adalah keterampilan guru dalam menciptakan dan memelihara kondisi belajar yang optimal dan mengembalikannya manakala terjadi hal-hal yang dapat mengganggu suasana. Pengelolaan kelas meliputi pengelolaan beberapa benda/alat serta obyek yang terdapat di dalam kelas atau tempat belajar seperti: meja dan kursi baik guru maupun murid, pajangan yang merupakan hasil karya siswa, perabot sokolah, serta sumber belajar yang terdapat di dalam kelas.

Menurut Syaiful Bahri Djamarah dan Aswan Djain (2002:5) tujuan pengelolaan kelas adalah agar setiap anak di kelas dapat bekerja dengan tertib sehingga segera tercapai tujuan pengajaran secara efektif dan efisien. 
Berbagai pendekatan dapat dilakukan oleh guru dalam mengelola kelas. Menurut Syaiful Bahri Djamarah dan Aswan Djain (2002:5) pendekatan yang dapat dilakukan untuk mengelola kelas meliputi: 1) pendekatan kekuasaan, 2) pendekatan ancaman, 3) pendekatan kebebasan, 4) pendekatan resep, 5) pendekatan pengajaran, 6) pendekatan tingkah laku, 7) pendekatan suasana emosi dan hubungan sosial, 8) dan pendekatan electics atau pluralistic.

Sebagai upaya memperkecil masalah gangguan dalam mengelola kelas, beberapa prinsip mengelola kelas dapat dipergunakan sebagai berikut; 1) Hangat dan antusias, 2) Tantangan, 3) Bervariasi, 4) Keluwesan, 5) Penekanan pada hal-hal positif, dan 6) Penanaman disiplin diri.

Secara umum komponen keterampilan pengelolaan kelas dibagi menjadi dua bagian, yaitu keterampilan yang berhubungan dengan penciptaan dan pemeliharaan kondisi belajar yang optimal (bersifat preventif) dan keterampilan yang berhubungan dengan pengembangan kondisi belajar yang optimal dengan cara penyediaan fasilitas bagi bermacam-macam kegiatan belajar siswa dalam lingkungan sosial, emosional, dan intelektual di kelas.

\section{SIMPULAN}

Melihat dari beberapa pendapat ahli yang telah dikemukakan di atas mulai dari pengertian, kompetensi serta peran seorang guru, sudah selayaknya seorang guru disebut sebagai manajer yang sebenarnya di sekolah, sebagaimana arti dari manajemen adalah mengarahkan atau memimpin suatu daya usaha melalui perencanaan, pengorganisasian, dan pengendalian sumber daya manusia dan ditujukan untuk mencapai tujuan yang telah ditentukan sebelumnya dan manajemen juga sebagai seni dan ilmu perencanaan, pengorganisasian, pengarahan, pengkoordinasian, dan pegontrolan dari pada " human dan natural resources" untuk mencapai tujuan organisasi yang ditentukan terlebih dahulu,manajemen adalah proses perencanaan, pengorganisasian, memimpin, dan mengawasi usaha-usaha dari anggota organisasi dan sumber-sumber organisasi lainnya untuk mencapai tujuan organisasi yang telah ditetapkan. Dalam buku tentang dasar-dasar manajemen, para ahli mendefinisikan manajemen sebagai suatu 
proses tertentu yang terdiri dari planning (perencanaan), organizing (pengorganisasian), actuating (penggerakan) dan controlling (pengawasan) dengan menggunakan seni dan ilmu pengetahuan untuk setiap fungsi tersebut dan merupakan petunjuk dalam mencapai tujuan yang telah ditentukan terlebih dahulu.

Dari sejumlah definisi tentang manajemen yang telah dikemukakan di atas, sudah selayaknya jika seorang guru dikatakan sebagai seorang manajer di sekolah dimana tempat ia mengajar.

\section{DAFTAR PUSTAKA}

Desler, Garry. 1997. Manajemen Sumber Daya Manusia, Jakarta; Prenhallindo.

Djamarah, Syaiful Bahri. 2000. Guru dan Anak Didik dalam Interaksi Edukatif, Jakarta: PT Rineka Cipta.

Ginanjar, M. Hidayat. 2015. Tantangan dan Peluang Lembaga Pendidikan Islam Di Era Masyarakat Ekonomi ASEAN (MEA), Volume 04 No.08, Juli 2015, Edukasi Islami, Jurnal Pendidikan Islam.

Manulang, M. 1978. Dasar-dasar Manajemen, Jakarta; Ghalia Indonesia.

Maya, Rahendra. 2013. "Esensi Guru dalam Visi-Misi Pendidikan Karakter". Edukasi Islami: Jurnal Pendidikan Islam Program Studi Pendidikan Agama Islam Jurusan Tarbiyah Sekolah Tinggi Agama Islam (STAI) AI Hidayah Bogor. Vol. 03 No. 02 Edisi Januari 2013.

Mulyasa, E. 2002. Manajemen Berbasis Sekolah, Bandung; PT Remaja Rosda Karya.

Purwanto, M. Ngalim, dkk. 1992. Administrasi Pendidikan. Jakarta: Mutiara Sumber Widya.

Undang-undang RI No.14 tahun 2005, Tentang Guru dan Dosen, Jakarta: fokus Media.

Usman, Moh. Uzer, 2006, Menjadi Guru Profesional. Bandung: ; PT Remaja Rosda Karya.

Wiriadiharja, Moefti. 1987. Dimensi kepemimpinan dalam Manajemen, Jakarta Balai Pustaka. 